\title{
A life-cycle approach to food and nutrition security in India
}

\author{
Rajesh Kumar Rai ${ }^{1, *}$, Sandhya Kumar ${ }^{1}$, Madhushree Sekher ${ }^{2}$, Bill Pritchard ${ }^{3}$ and \\ Anu Rammohan ${ }^{4}$ \\ ${ }^{1}$ Tata Institute of Social Sciences, V N Purav Marg, Deonar, Mumbai 400088, Maharashtra, India: ${ }^{2}$ Centre for Study \\ of Social Exclusion and Inclusive Policies, Tata Institute of Social Sciences, Mumbai, India: ${ }^{3}$ School of Geosciences, \\ The University of Sydney, Sydney, Australia: ${ }^{4}$ School of Business, Discipline of Economics, The University of Western \\ Australia, Crawley, Australia
}

Submitted 21 August 2013: Final revision received 16 April 2014: Accepted 28 April 2014: First published online 27 May 2014

\begin{abstract}
India's poor performance on critical food and nutrition security indicators despite substantial economic prosperity has been widely documented. These failings not only hamper national progress, but also contribute significantly to the global undernourished population, particularly children. While the recently passed National Food Security Act 2013 adopts a life-cycle approach to expand coverage of subsidized food grains to the most vulnerable households and address food security, there remains much to be desired in the legislation. Access to adequate food for 1.24 billion people is a multifaceted problem requiring an interconnected set of policy measures to tackle the various factors affecting food and nutrition security in India. In the present opinion paper, we discuss a fivefold strategy that incorporates a life-cycle approach, spanning reproductive health, bolstering citizen participation in existing national programmes, empowering women, advancing agriculture and better monitoring the Public Distribution System in order to fill the gaps in both access and adequacy of food and nutrition.
\end{abstract}

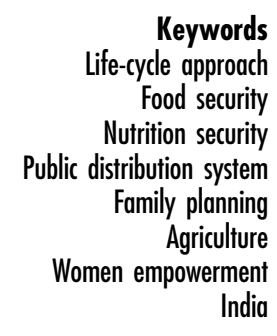

Food insecurity remains a grim reality for millions of Indians. According to the 2013 Global Hunger Index ${ }^{(1)}$, with a population of 1.24 billion, over $17 \%$ of India's population is undernourished. In addition, the 2011 HUNGaMA Report ${ }^{(2)}$ estimated that $42 \%$ of Indian children under 5 years of age were underweight, which accounts for India having the highest number of undernourished children globally. This is also among the leading causes for India having the highest number of child (under-five) deaths in the world ${ }^{(3)}$. India joined 188 other countries in 2000 to endorse the Millennium Declaration, committing to halve the proportion of people who suffer from hunger by 2015 (Millennium Development Target: 1c). Although the hunger reduction target was deemed globally achievable, India's performance has remained unacceptably poor ${ }^{(4,5)}$. In order for the global achievement of these goals, it is imperative for India to reassess its policies to tackle the food and nutrition insecurity plaguing its population.

Food security is achieved when 'all people, at all times, have both physical and economic access to sufficient food to meet their dietary needs for a healthy and productive life, (6). For several decades, the Public Distribution System (PDS) has been the chief policy instrument used by the Government of India to address the food security needs of its citizenry ${ }^{(7)}$. The PDS was intended to meet the twin objectives of granting price support to farmers for their crops and spurring enough agricultural production to secure national buffer stocks ${ }^{(8)}$. The PDS, however, was widely criticized for its failure to serve those below the poverty line, its urban bias, negligible coverage in the states with the highest concentration of the rural poor, and lack of accountable delivery arrangements ${ }^{(9)}$. The tipping point finally came when in tandem with these operational failings, the PDS grew to be fiscally untenable for the central government ${ }^{(10)}$.

In light of these factors, the government introduced the Targeted Public Distribution System (TPDS) in $1997^{(11)}$. With the TPDS, the government trimmed the PDS from a universal system, to creating classifications of food-grain beneficiaries and their entitlements according to monthly household income. The three broad categories established were households above the poverty line (APL), below the poverty line (BPL), and households deemed the poorest of the poor, named Antyodaya Anna Yojana (AAY) ${ }^{(11)}$. As per its eligibility, each household is issued a ration card identifying its household status among the three groups and its respective entitlements at the local Fair Price Shop (FPS). However, the current methodology for determining eligible beneficiaries has yielded substantial targeting errors by excluding eligible BPL households and including APL 
households, thus diverting subsidized food grains from intended households ${ }^{(12,13)}$. Furthermore, the operation of the TPDS is rife with leakages from the procurement process to the point of delivery at the FPS, as well as poor infrastructure to store procured food grains ${ }^{(9)}$.

Recent years have seen renewed debate on the issues of food security and the TPDS in India. At the centre of this conversation has been the National Food Security Act (NFSA), a bill passed in $2013^{(14)}$ that grants food subsidies to $75 \%$ of rural and $50 \%$ of urban households. In addition, the bill gives pregnant women and mothers a maternity benefit of at least 6000 Indian Rupees (Rs) ${ }^{(14)}$. While the NFSA has expanded its coverage of beneficiaries and reduced prices for rice, wheat and coarse grains through the TPDS to Rs 3, 2 and 1 per kilogram, respectively, there are still significant shortcomings in the bill. The NFSA scarcely provides any reforms to the TPDS, which has a history of mismanagement and leakages. Additionally a 'right' to food is somewhat misleading considering that the programme will not be universal and will exclude households. The exclusion and inclusion errors reported over the years since the TPDS attempted to target households that were above and below the poverty line saw the exclusion of countless vulnerable households, and no alternative measure has been proposed in the new bill. Finally, many question the quantity and diversity of the foods the NFSA subsidizes through the TPDS to improve overall nutrition, both from a caloric and qualitative perspective $^{(15)}$. Rice and wheat alone cannot make up for the array of critical vitamins, minerals and other nutritional inputs necessary for the healthy development and functioning of individuals, particularly growing infants and children. In its current form, the NFSA still falls short of achieving the WHO's criteria of nutrition for 'an adequate, well balanced diet.'

The text of the NFSA ${ }^{(14)}$ claims to adopt a 'life-cycle approach' to food and nutrition security for India, through food subsidies and interventions at different stages from birth through adulthood and old age. However, the NFSA presents few guidelines to follow the nuanced life-cycle approach, thus raising questions about the ultimate effectiveness of the Act. The present opinion paper calls for a re-examination of what a life-cycle approach to food and nutrition security in the Indian context requires and proposes a multi-pronged approach to address it.

\section{Life-cycle approach to food and nutrition security}

India is now entering the final stage of demographic transition, whereby current fertility transition and its future trends may completely redefine India's population. The ultimate size of India's population when population stabilization is achieved will be about 1.72 billion around the year $2060^{(16)}$. The fertility decline indicates that the total number of members in a household is decreasing. This has coincided with increasing survival rates that has decreased the mean household size slightly from 5.7 in 1992-93 to $5 \cdot 1$ in $2007-08^{(17)}$.

Food grain needs depend on age and sex structure, as well as the consumption pattern of a particular household. According to the 2011 census ${ }^{(18)}, 10 \%$ of India's population is between the ages of 0 and 4 years, $21 \%$ is between the ages of 10 and 19 years (youth), and almost $9 \%$ is 60 years of age and older. Over $50 \%$ of women belong to the reproductive-age group (15-49 years) and need stable food and nutrition security in order to improve overall maternal and child health outcomes. In order to cater to the food and nutrition requirements of children, youths, adults, as well as the elderly, a sustainable integrated approach targeting the different stages of life is imperative.

In general, food access, food availability and food adequacy at the individual level are influenced by several factors, the most important of which is poverty ${ }^{(19)}$. Other factors include the national and international economic environment, population growth, infrastructure, the climate, the level of aid donor commitment and intervention, access to appropriate training and job skills, asset base, conflict and access to pasture, and the quality of diet, health and sanitation ${ }^{(19)}$. The insufficiency of food production does not necessarily cause food inadequacy as is evident in India, which is the largest rice producer in the world for a second consecutive year. It is estimated that 35 to $40 \%$ of fresh produce in India is lost because neither wholesale nor retail outlets have cold storage, even though the Food Corporation of India maintains a minimum level of buffer stock ${ }^{(20)}$. In addition, an independent evaluation of the PDS by the Planning Commission of India reported that due to leakages and diversion of food grains, only $42 \%$ of subsidized food grains reached the target group $^{(9)}$. There has been great discussion on the need for food entitlements to be adjusted for household size in India ${ }^{(21)}$. Food insufficiency acutely affects most of the poor, who often also have more children. However, the Indian government has not adjusted PDS entitlements per month according to changing household size, nor has any serious evidence explained the rationale behind the allotment of $5 \mathrm{~kg}$ of food grains per person per month under the new bill.

As India was struggling to increase subsidies required to implement the NFSA, during the Ministerial Conference of the World Trade Organization (WTO) in Bali, Indonesia in December 2013, some members of the WTO claimed that raising subsidies would be in violation of India's commitments under the WTO Agreement on Agriculture (AoA), $1995^{(22)}$. This specifically refers to the aggregate measure of support (AMS) provided by India to its farmers during the procurement of basic food grains for the operation of the expanded PDS. For India, however, the matter of food security was non-negotiable, and it was estimated that although India's agricultural support has increased relative to pre-2005 levels, it does not require special protection and the implementation of the NFSA is still well within the limits 
committed to by India and within the span of permissible provisions under the WTO's AoA ${ }^{(23)}$. At the end of the closed-door meetings, negotiators in Bali agreed to a 4-year peace clause, whereby they would not challenge India's food security measures before $2017^{(22)}$, and India promised that its policies would not 'distort trade or adversely affect the food security of other members ${ }^{\text {(24) }}$. While what happens after 2017 remains to be seen, the G-33 grouping of forty-six developing nations including India, China and Indonesia has proposed to amend the WTO's AoA in order to procure food grains from poor farmers at minimum support prices and sell to the poor at subsidized rates through national food programmes. This would not only be favourable for India but for developing countries at large ${ }^{(25)}$.

\section{A way forward}

Despite undertaking several programmes to address factors affecting food and nutrition security, such as income and health, India has still failed to curb the gaps in household food and nutrition security. To mitigate this problem we propose a fivefold approach that addresses critical interventions in the life cycle that can address the prevailing food and nutrition insecurity.

\section{Promote family planning}

Family planning is one of the earliest life-cycle interventions that can contribute to the reduction of hunger ${ }^{(26)}$. Demographic studies show that the fertility rate in poor households is higher than the national average, meaning larger household sizes. Promotion of rights-based family planning is the most cost-effective approach to bring down fertility, which in turn will help limit household size and lower foodgrain requirements ${ }^{(27,28)}$. The fact that only $47 \%$ of women aged 15-49 years reported using a modern method of contraception $^{(17)}$ indicates the potential for unintended pregnancy/births, which more starkly affect the poor who do not have enough economic support for daily living. Although India introduced the first comprehensive family planning programme in the world, it has always been underfunded $^{(26)}$. Slowing population growth to reduce household size requires greater encouragement of family planning programmes and support from different development sectors including finance, agriculture, water and the environment ${ }^{(29)}$. In order to encourage the use of family planning methods, the Indian government could devise a policy that limits fertility through incentives linked to other programmes, such as the PDS or Integrated Child Development Services (ICDS). For instance, a couple that decides to have two children or less may be entitled to receive some financial reward towards their children's education or health-care benefits. In 2013, the Ministry of Health and Family Welfare endorsed an inter-sectoral approach to reproductive, maternal, newborn, child and adolescent health $(\mathrm{RMNCH}+\mathrm{A})$ that aims to provide reproductive, antenatal, postnatal and child health care as part of a life- cycle approach ${ }^{(30)}$. As part of reproductive health care, the government plans to target village-level households and sub-centres to improve the coverage of contraceptive use.

\section{Boost participation in existing schemes}

The NFSA mentions existing programmes like the ICDS and the Mid Day Meal (MDM) scheme for schoolchildren; however, it provides no insight on how to better integrate these schemes with the TPDS or improve their implementation. This is essential for a successful life-cycle approach, since such interventions have a specific time frame within which pregnant women, mothers and young children must gain access to nutritional and medical benefits $^{(31-33)}$. The MDM scheme was launched in 2001 to introduce cooked mid-day meals in primary schools to boost both school attendance as well as ensure a baseline of nutrition among young children ${ }^{(34)}$. Children under 6 years of age can also get food supplements through the ICDS, which administers a range of services to ensure the healthy physical and cognitive development of children through a network of community centres, called anganwadis $^{(35)}$. However, ICDS has lagged in improving child and maternal nutrition, primarily due to a lack of awareness and participation in local communities. For a poor household that does not have sufficient income to feed all household members daily, these programmes can make a critical difference. In addition, the ICDS provides health and nutrition services that can be vital in the healthy development of children, thus decreasing child mortality and reduce the need to continue having children. Since these interventions must be carried out within a specific window of time, boosting participation in these schemes is imperative.

Apart from the PDS, the Government of India has made an effort to address problems of access to nutrition due to unemployment or low wages through the Mahatma Gandhi National Rural Employment Guarantee Act (MNREGA). Under this act, any adult willing to do casual labour at the minimum wage is entitled to employment on local public works within $15 \mathrm{~d}$ of registration for work, subject to a limit of $100 \mathrm{~d} /$ household per year ${ }^{(35)}$. Evidence shows that those who participate in MNREGA often suffer from acute poverty making them more vulnerable to various socio-economic shocks and limiting their access to food grains from PDS ${ }^{(35)}$. Recent studies on the MNREGA performance suggest a significant reduction in rural poverty and improved economic support for households to purchase required food in states like Andhra Pradesh, Himachal Pradesh, Rajasthan, Tamil Nadu and Sikkim ${ }^{(35)}$. Therefore it is crucial that greater outreach for MNREGA be conducted and employment opportunities made available so that people are able to purchase subsidized foods under PDS, as well as fulfill other dietary needs.

While the NFSA focuses on child, maternal and adult food security from a life-cycle approach, there is little mention of the vulnerable state of the growing elderly population in the country, who must often balance food 
insecurity with various health ailments and little financial support to resolve either. Currently within PDS there is a scheme called Annapurna Yojana, which gives those who are 65 years of age and older, as well as those eligible for old age pension but in non-receipt, $10 \mathrm{~kg}$ of food grains monthly per person at no cost. However, this amount of grains neither supports their caloric needs nor their unique nutritional needs to keep health problems at bay.

\section{Women's role in bousebold food security}

The NFSA makes a notable shift by making the eldest woman above the age of 18 years the head of the household for issuing ration cards for the TPDS. This is a progressive step in light of how, in many parts of India, women lack decision-making power, especially regarding reproductive health and basic household spending ${ }^{(36)}$. However, a life-cycle approach for aiding women achieve food and nutrition security must begin earlier, through programmes that help women complete their education and which can benefit both agriculture and health. Girls who complete their schooling are empowered to participate in household decision making, leading to smaller, healthier families. Furthermore, an educated woman is better equipped to pursue business or employment opportunities that contribute to a family's financial well-being ${ }^{(29)}$. A study conducted by the FAO showed that women farmers are 20 to $30 \%$ less productive than men, but not due to some lapse in managing their farms or level of effort ${ }^{(37)}$. The main culprit in this disparity was the female farmer's lack of access to resources that are more easily available to men, such as land, financing, training and technology ${ }^{(37)}$. With the same access to such tools, women could produce 20 to $30 \%$ more food and their families would see improved health, nutrition and education ${ }^{(37)}$.

The growing role of women in PDS service provisioning in India has been witnessed in some states. For instance, the government of Odhisa gives priority to women's selfhelp groups to operate FPS which distribute PDS grains. In one instance, realizing the irregularity in food-grain distribution by the civil supply department in a remote part of Gajapati district in the state of Odisha, a women's self-help group took over the licence to run the PDS for the gram panchayat (the administrative body at the village level) ${ }^{(38)}$. Under the charge of the twenty-one women in the self-help group, store operations were actually able to benefit the 236 BPL families and 131 economically vulnerable families in the village ${ }^{(38)}$.

\section{Linking agriculture, nutrition and bealth}

Stepping back from the household level, there is an urgent need for India to evaluate the state of agriculture as a whole, which still employs two-thirds of its labour force. The NFSA does mention some goals for reinvesting in agriculture, improving infrastructure and assisting smallscale farmers, however none of these have any legal shape or form; they are to be 'progressively realized'. Programme and policy makers are striving to link agriculture, nutrition and health programmes ${ }^{(39)}$. Innovative examples from the field show that beneficiaries, community leaders and practitioners recognize the benefits of programmes that integrate health needs, including family planning, into efforts to improve agricultural systems ${ }^{(29)}$. Integrated programmes, through agricultural extension programmes that include communication and learning activities by educators from different disciplines, may be more successful at reaching rural people who have no access to health systems. This would engage men who receive little information about family planning, as well as reach women more efficiently with health, nutrition and agriculture services ${ }^{(29)}$. Increasing support for innovative research for programmes that bridge the agriculture and health sectors can lead to a new generation of initiatives for reducing hunger ${ }^{(29)}$.

To ensure not just adequate food production for the expanded coverage under the NFSA and TPDS, but also elevate the quality and diversity in food baskets, a new farming revolution is required. The NFSA does include coarse grains in the provision of subsidized foods; however, recent trends ${ }^{(40)}$ show that many farmers switch to rice and wheat production as it often yields better prices from the government, even though millets and other coarse grains provide essential nutrition. In respecting a life-cycle approach, the government must take steps that do not force farmers to have to fend for sustenance, often by changing to untenable cultivation activities or leaving agriculture entirely. Instead they must support farmers who can deliver a more diverse food basket. To strengthen agricultural activities that can improve nutrition and health, the government could give commensurate incentives to farmers of alternative nutritious crops. Additionally, the government could introduce specific health and nutrition interventions such as micronutrient supplementation ${ }^{(39)}$.

It is encouraging to note that the Government of India has decided to establish a Prime Minister's National Council on India's Nutrition Challenges for policy direction, review and effective coordination between multiple ministries. These include the Ministry of Human Resource and Development, the Ministry of Agriculture, Consumer Affairs, Food and Public Distribution, the Ministry of Health and Family Welfare, the Ministry of Women and Child Development, the Ministry of Rural Development, and the Ministry of Urban Development, the Ministry of Information and Broadcasting, and the Ministry of Panchayati Raj ${ }^{(41)}$.

\section{Strengthening the monitoring and evaluation of TPDS performance}

As the spine of the NFSA, and the largest programme in place to household tackle food and nutrition security in India, it is imperative to plug the holes in TPDS operations. In an independent evaluation report submitted by the Programme Evaluation Organization instituted by the Planning Commission and the Ministry of Consumer Affairs, Food and Public Distribution of India in 2005, a 
performance evaluation of TPDS was included. The report questioned the outcome of the TPDS and reported that about $57 \%$ of subsidized grains did not reach the intended beneficiaries, of which over $36 \%$ was siphoned out of the supply chain ${ }^{(9)}$. It also stated that the implementation of TDPS was plagued by large inclusion and exclusion errors in the identification of eligible beneficiaries ${ }^{(9)}$. It is perhaps with these failures in mind that the new food security bill adds a new level of monitoring of the TPDS, through the appointment of a District Grievance Redressal Officer as well as a State Food Commission. Whether more layers of a bureaucracy will promote better surveillance and grievance redressal of affected beneficiaries is unclear. However, some states have taken significant measures independently that have yielded improvements in the operations of their TPDS. The state of Chhattisgarh has already computerized much of its operations, from listing all beneficiaries and their entitlements online, to texting beneficiaries when food deliveries will be made to local FPS $^{(42)}$, thus increasing transparency and accountability. Pushing for comprehensive e-governance and computerization of PDS operations, along with more involvement of Panchayati Raj institutions (Panchayati Raj is a system of governance in which village-level administrative bodies called Panchayats are the basic units of administration in India), gives people in local communities greater control in monitoring their TPDS.

\section{Conclusion}

As home to the largest number of undernourished children globally, a well-functioning PDS in India could have a significant impact on improving nutrition among adults and children. Recent statistics show that the share of PDS purchases in total rice consumption in 2009-10 was about $23.5 \%$ in the rural sector and about $18 \%$ in the urban, whereas in 2004-05, the PDS share in total rice consumption had been about $13 \%$ in the rural sector and $11 \%$ in the urban ${ }^{(43)}$. This indicates an improvement in the overall use and delivery of the PDS between 2004 and 2010. However, this improvement has failed to manifest in improved nutritional outcomes. Investments in health services, women's empowerment, education and building awareness among the most vulnerable groups are critical to improving food and nutrition security in India.

While the new food security act, and particularly the life-cycle approach, is a step in delivering legal rights to the people to claim their food entitlements, it is just one piece of the puzzle. India's nutrition crisis is multifaceted, as evident in our fivefold approach that looks deeper at what a life-cycle approach requires. Improving access to family planning is a critical part of fulfilling future food needs, and food security and nutrition advocates must add their voices to support investments in rights-based family planning as an essential complement to agriculture and food policy solutions. Strengthening the PDS monitoring and evaluation system is key to guaranteeing that food grains are reaching their rightful beneficiaries and mitigating food insecurity in households. The priority of the Indian government should be to create a system of income support and economic security ${ }^{(35,44)}$ that in the long run will make people less dependent on the subsidies of the PDS and better able to ensure the needed food diversity for optimum nutrition.

There is promise in the current policy movements and integrating the myriad components affecting nutrition across different stages of human life, as advocated for in the present opinion paper. It provides hope for not just turning around India's nutritional insecurity, but also for setting a comprehensive model to ensure food security to all citizens in low-income countries.

\section{Acknowledgements}

Financial support: This research received no specific grant from any funding agency in the public, commercial or notfor-profit sectors. Conflict of interest: None. Authorship: R.K.R., S.K., M.S., B.P. and A.R. provided intellectual input through different stages of preparation of this manuscript equally. Ethics of buman subject participation: Ethical approval was not required.

\section{References}

1. International Food Policy Research Institute (2013) Global Hunger Index - The Challenge of Hunger: Building Resilience to Achieve Food and Nutrition Security. Bonn/ Washington, DC/Dublin: IFPRI.

2. Nandi Foundation (2011) HUNGaMA: Fighting Hunger and Malnutrition. Hyderabad: Nandi Foundation.

3. World Health Organization \& UNICEF (2013) Accountability for Maternal, Newborn and Child Survival: The 2013 Update. Geneva: WHO.

4. United Nations (2013) The Millennium Development Goals Report 2013. New York: UN.

5. Banerjee AV \& Duflo E (2007) The economic lives of the poor. J Econ Perspect 21, 141-167.

6. US Agency for International Development (1992) Policy Determination: Definition of Food Security. Washington, DC: USAID.

7. Food Corporation of India (2013) Brief Note on PDS and other Welfare Schemes. New Delhi: FCI, Government of India.

8. Ramaswami B (2002) Efficiency and equity of food market interventions. Econ Polit Wkly 37, 1129-1135.

9. Planning Commission (2005) Performance Evaluation of Targeted Public Distribution System (TPDS). New Delhi: PEO, Planning Commission, Government of India.

10. Anon. (2013) Food security works will hike fiscal deficit: FICCI. Deccan Herald. http://www.deccanherald. com/content/346142/food-security-works-hike-fiscal.html (accessed April 2014).

11. Kattumuri R (2011) Food Security and the Targeted Public Distribution System in India. Asia Research Centre (ARC) Working Paper no. 38. London: London School of Economics \& Political Science.

12. Khera R (2011) Revival of the Public Distribution System: evidence and explanation. Econ Polit Wkly 66, 36-50. 
13. Dev SM \& Sharma AN (2010) Food Security in India: Performance, Challenges and Policies. Oxfam India Working Papers Series no. OIWPS - VII. New Delhi: Oxfam India.

14. Ministry of Law and Justice, Government of India (2013) The National Food Security Act. The Gazette of India. New Delhi: Government of India.

15. Dreze J (2013) The food security debate in India. The New York Times. http://india.blogs.nytimes.com/2013/07/09/ the-food-security-debate-in-india/?_r=0 (accessed April 2014).

16. James KS (2011) India's demographic change: opportunities and challenges. Science 333, 576-580.

17. International Institute for Population Sciences (2010) District Level Household and Facility Survey 2007-08. Mumbai: IIPS.

18. Office of Registrar General and Census Commissioner, Ministry of Home Affairs, Government of India (2011) Population Enumeration Data (Final Population). http:// www.censusindia.gov.in/2011census/population_enumeration. aspx (accessed April 2014).

19. Cohen D (2005) Achieving food security in vulnerable populations. BMJ 331, 775-777.

20. Godfray HCJ, Beddington JR, Crute IR et al. (2010) Food security: the challenge of feeding 9 billion people. Science 327, 812-818.

21. Puri R (2012) Loud no to cash. Frontline 28, 106-107.

22. Anon. (2013) Why the WTO agreement in Bali has finally helped developing countries. The Guardian. http://www. theguardian.com/global-development/poverty-matters/2013/ dec/06/wto-agreement-bali-helped-developing-countries-india (accessed April 2014).

23. Narayanan S (2014) The National Food Security Act vis-à-vis the WTO agreement on agriculture. Econ Polit Wkly 49 40-46.

24. World Trade Organization (2013) Public stockholding for food security purposes (draft ministerial decision). https:// mc9.wto.org/system/files/documents/w10_1.pdf (accessed April 2014).

25. Anon. (2013) The WTO's Bali Ministerial and food security. Econ Polit Wkly 48, 70-72.

26. Osotimehin B (2012) Family planning saves lives, yet investments falter. Lancet 380, 82-83.

27. Kaiser J (2011) Does family planning bring down fertility? Science 333, 548-549.

28. Cates W Jr, Karim QA, El-Sadr W et al. (2010) Family planning and the Millennium Development Goals. Science 329, 1603.
29. Bremner J (2012) Population and Food Security: Africa's Challenge. Population Reference Bureau Policy Brief February 2012. Washington, DC: PRB.

30. Ministry of Health and Family Welfare, Government of India (2013) A Strategic Approach to Reproductive, Maternal, Newborn, Child and Adolescent Health $(\mathrm{RMNCH}+\mathrm{A})$ in India. New Delhi: Government of India.

31. Scrimshaw NS (1996) Nutrition and health from womb to tomb. Nutr Today 31, 55-67.

32. Conti G, Hansman C, Heckman JJ et al. (2012) Primate evidence on the late health effects of early-life adversity. Proc Natl Acad Sci USA 109, 8866-8871.

33. Conti G \& Heckman JJ (2013) The developmental approach to child and adult health. Pediatrics 131, Suppl. 2, S133-S141.

34. Anon (2011) Editorial: Malnutrition and ICDS. Econ Polit Wkly 66, 9.

35. Dreze J \& Sen A (2013) An Uncertain Glory: India and Its Contradictions. New Delhi: Allen Lane, Penguin Group, Thompson Press India Ltd.

36. Dyson T \& Moore M (1983) On kinship structure, female autonomy, and demographic behavior in India. Popul Dev Rev 9, 35-60.

37. Food and Agricultural Organization of the United Nations (2011) FAO at Work 2010-2011: Women - Key to Food Security. Rome: FAO.

38. Anon. (2007) Women self-help group dons role of PDS dealer. The Hindu. http://www.hindu.com/2007/02/ 02/stories/2007020215240300.htm (accessed April 2014).

39. Pinstrup-Andersen P (2013) Nutrition-sensitive food systems: from rhetoric to action. Lancet 382, 375-376.

40. Banerjee K (2011) Decentralized procurement and universalized PDS. Econ Polit Wkly 46, 19-22.

41. Prime Minister of India (2013) PM's National Council on India's Nutrition Challenges. New Delhi: Prime Minister's Office; available at http://pmindia.nic.in/committeescouncils_ details.php?nodeid $=14$

42. One World Foundation (2011) Computerisation of paddy procurement and public distribution system in Chhattisgarh. http://indiagovernance.gov.in/files/PDSChattisgarh_best practice_final.pdf (accessed April 2014).

43. National Sample Survey (2013) Public Distribution System and Other Sources of Household Consumption. NSS 66th Round. New Delhi: Ministry of Statistics and Programme Implementation, Government of India.

44. Maurice J (2013) New goals in sight to reduce poverty and hunger. Lancet 382, 383-384. 